\title{
An Analysis of Code Mixing in the MOVIE "From London to Bali"
}

\author{
Andi Asrifan \\ Universitas Muhammadiyah Sidenreng Rappang, Indonesia \\ andiasrifan@gmail.com \\ Harun Abdullah \\ STIE Indonesia Makasar, Indonesia \\ abdullahharun434@gmail.com \\ Muthmainnah \\ Universitas Al Asyariah Mandar, Indonesia \\ muthmainnahunasman@gmail.com \\ Muhammad Yunus \\ Universitas Muhammadiyah Sidenreng Rappang, Indonesia \\ muhammadyunusmaiwa@gmail.com
}

\begin{abstract}
Atul Patil
School of Holistic Development, MIT Art, Design \& Technology University, Pune, INDIA atul.patil@mituniversity.edu.in
\end{abstract}

\begin{abstract}
This study aims to analyze the code-mixing from London to Bali movies. What was be examined is the types and level code-mixing. In types and level code-mixing, researchers used the Suwito theory. As for the types of code-mixing, including inner code-mixing and outer code-mixing, while in code-mixing level consists of six words: word-level code-mixing, phrase-level code-mixing, clause level code, baster level codemixing, repetition level code-mixing, and code-mixing level idioms. This research design used is qualitative research. Qualitative research, among others, is descriptive. The data is collected more in the form of words or pictures rather than numbers. The qualitative descriptive method is a method that researchers can use to analyze by doing fact-finding with the right interpretation. Qualitative research is closely associated with the context. Based on the results of the analysis from London to Bali, the data was obtained for types of code-mixing consisting of inner code-mixing 115 data, outer codemixing 46 data, and level code-mixing consisting of word-level code-mixing 145 data, phrase level code-mixing 10 data, code-mixing clause level 4 Data, baster level codemixing 1 data, repetition level code-mixing 3 data, idiom level code-mixing 0 data.
\end{abstract}

\footnotetext{
ENGLISH FRANCA : Academic Journal of English Language and Education

Vol. 5, No. 2, 2021, IAIN Curup

P-ISSN 2580-3670, E-ISSN 2580-3689

DOI: $10.29240 /$ ef.v5i2.2619
} 
318 | ENGLISH FRANCA, Vol. 5, No. 2, 2021

Keywords: Analysis, Code-mixing, Movie

\section{INTRODUCTION}

Software applications, television, telephone, CD ROM, audio or movie, computer, and internet are all examples of ICT. The movie as an example of how ICT may be used as a communication medium takes a role as a communication medium (Apriani, et. al, 2019). The movie is the work of most people who cooperated in making works of art to display on the screen, such as the cinema and other communications tools. To make a movie in need of hard work to work a movie that was being created. This is caused because the start of wrote a story movie, the place of movie, the main cast and supported, and it's a lot of other needs in need in the made of a movie (Rohrbach, Torabi, Rohrbach, Tandon, \& ..., 2017). All this is done to get the results that work the best to show to the broader community. The success of work can be determined by how enthusiastically people watch the work, particularly a movie. It is a tool of mass communication, a tool for disseminating various message types in modern civilization is, in the use of other movies, be a tool for the artists of the movie to express ideas, through insight into beauty (Mendiburu, 2012).

The most important thing in the making of the movie is the storyline that was explained in the movie and the background such as popular movies, actors and actresses who play the movie, and the use of language in the making of the movie (Angarita, 2007; Moretti, 2011). With the advancement of communication media, the use of language today will spread more quickly, resulting in this type of code-mixing. Code-mixing can be found in magazines, novels, newspapers, radio broadcasts, social media, and movies. It's a fascinating phenomenon in Indonesia today, especially the use of Indonesian-English code-mixing in films. Movies are no longer just made to entertain people; they are also used to convey messages. Language messages are communicated through the medium. People use the language in a variety of ways. Code-mixing is one of them. Teenagers frequently use code-mixing. They frequently use a combination of Indonesian and English. One of the factors that cause teenagers to mix languages is the influence of movies, particularly popular films that contain code-mixing so that the movies influence language use (Adrean, Daud, \& Kismullah, 2019).

Then, the most prominent in the film is the cast that will play the characters because most people were interested in who was portraying the characters in the film (Butler, Wulff, Stanley, and Black). Aside from the cast, the majority of the views were used for filming. The film itself is a form of entertainment for the larger community to fill in spare time with family at home, at the movies, or wherever it is on the sidelines, busy with work draining.

The movie's groove or story depicts the interactions that exist in the film. And the movie, which is frequently seen by many people now that the grooves are present in the film, used code-mixing (Zhang \& Skiena, 2009). Code-mixing is used to make the film appear elegant, interesting to watch, and improve the film's grade (Busby \& Klug, 
2001). The more a groove is interested in a movie to be made, the more likely the audience is to watch the movie. In Indonesian films, there is frequently a mix of languages in use, either through code-mixing or subtitles. Code-mixing is the process of switching from one language to another using the same word or in the same oral or written text (Poudel, 2019). When someone uses a word or phrase from another language, it indicates that he or she is code-mixing (Poudel, 2019).

All of the above, especially for a movie in use in Indonesia, often used code-mixing and code-switching because in Indonesia, known with the bilingual community or community who can use two languages. Namely the regional languages as mother tongue and language and Indonesian as the national language and even a lot of the public who already know two languages from other Countries especially English as an international language. This is because Indonesia consists of many tribes' customs and cultural backgrounds are different. That is cause almost every region in Indonesia has a local language respectively. Therefore, Indonesia, known to the public is bilingual. It is the use of two or more languages sufficiently to carry on a limited casual conversation. From the community bilingual which causes code-mixing and codeswitching in Indonesia. In addition, almost every interaction in the community already uses code-mixing and code-switching in interacting well at home, market, and school wherever it is. (Harya, 2018)

Some studies done with a similar analysis found out the type of code-mixing used in dialogue in The Professionals Movie. The sources of data were the dialogue of The Professionals movie. The authors analyze the type of code-mixing. The results of the analysis will be displayed and analyzed. The author uses 127 pieces of data from the artist's dialogue in the movie that is sufficient to represent each code. The analysis focuses on five types of code-mixing: code-mixing informs of word insertion, phrase insertion, hybrid insertion, idiom, and clause insertion. The results of the analysis reveal that 127 dialogues are code-mixing, five forms of code-mixing: word insertion $(47,24 \%)$, phrase insertion $(18,11 \%)$, hybrid insertion $(1,57 \%)$, idiom insertion $(3,14 \%)$ and clause insertion $(29,92 \%)$ (Silviyani, 2018).

Another researcher, S. Rasul, discovered that code-mixing is common in social media content generated by multilingual users in his study. The processing of such data for linguistic analysis and computational modeling is difficult due to the linguistic complexity caused by the nature of the mixing, as well as the presence of non-standard spellings, grammar, and transliteration. Our analysis demonstrates the extent to which code-mixing occurs in English-Hindi data. The classification of Code mixed words based on the frequency and linguistic typology emphasizes that, while there are easily identifiable cases of borrowing and mixing at both ends, the vast majority of the words form a continuum in the middle, emphasizing the need to handle these at different levels for automatic data processing. (Rasul, 2013)

It's not the case with Hamsia, who discovered Because multilingual speakers frequently switch between languages, automatic language identification becomes both a necessary and difficult task. A simple unsupervised dictionary-based approach 
supervised word-level classification with and without contextual clues, and sequence labeling using Conditional Random Fields are all used. He discovered that the dictionary-based approach is outperformed by supervised classification and sequence labeling and that contextual cues must be considered (Hamsia, 2015). Other researchers argue that it should also take into account movie viewing habits on devices other than televisions. (Nair et al., 2019; Auerbach et al., 2019; Skerlos et al., 2019)

What distinguishes this research is that it will examine the movie in the case to learn more about the code-mixing that appears in the research subject, by watching the movie that was quite interesting used by the movie's actor from London to Bali. Its purpose is to broaden the research and educate the public about what code-mixing entails.

\section{THEORITICAL FRAMEWORK}

\section{About Sociolinguistic}

As a part of linguistics, it is an interdisciplinary study with sociology, with the object of the research in which it relates language and social factors found in society (Mesthrie, 2009; Meyerhoff, n.d.) Sociolinguistics can be used in communication or interaction that provides guidelines in communicating by showing what language, language variety, or language style should be used when talking to certain people(Holmes, 2013; Hymes, 1971). As an object in sociolinguistics, language is not seen or approached as a language but rather as a means of interaction or communication in human society

\section{Bilingual}

The beginning of the formation of bilingualism lies in the existence of a language community which means the agreed language community as a communication tool. From the language community, a new theory will emerge regarding bilingualism and monolingual. Monolingual is a language community that uses one language, while bilingualism is the habit of using two languages in interactions with others(Blommaert, 2010; Trudgill, 2000)

\section{Code}

In human interaction with the other, they usually take differences in codes in differences in fettles. Code is a particular dialect or language that is used in every opportunity to communicate between two or more parties(Trudgill, 2000). As a general rule, code usage during a conversation has occurred commonly in bilingual societies. They can use some code in thanks. Can talk about who is talking to them. The decision codes are in various languages. It can be referred to all types of systems used by two or more people for communication. 


\section{Code-mixing}

Code-mixing was a phenomenon of bilingual that exists in the community are bilingual or multilingual. This is because people who use two languages or more often insert words that have no grammatical elements in them. In another word, say clause or phrase in use is composed of clauses ( hybrid clauses, hybrid phrases) and each clause or phrase no longer support the functions of its own then the events that happened is the code-mixing(Pitaloka, n.d.; Wray, 1998)

\section{Types of code-mixing}

There are several types of code-mixing said; there are three types of code-mixing based on syntactical pattern (Sotiloye, 1992) as follows :

a) Intra lexical code-mixing

b) Intra sentential code-mixing

c) Involving a change in pronunciation

Meanwhile, others divide the two code-mixing types: inner code-mixing and outer code-mixing(Bhatia \& Ritchie, 2014).

a) Inner code-mixing Code-mixing the code in the is to mix a language with its language. Usually, it happens in Indonesia, because Indonesia was many traditional languages in each region utter code-mixing

b) Outer code-mixing It is the mixing of languages derived from a foreign language. That is, speakers, mix the language of their nation with a foreign language. English is a foreign language which common people mix the language of their country with the English language.

c) Level of code-mixing While in the context of the level of code-mixing, it divides the types of codemixing into some words, phrases, baster, repetitive words, idioms and clauses.

\section{Movie}

The film is an audio-visual communication medium to convey a message to a group of people gathered in a certain place(Ainslie, Drèze, \& Zufryden, 2005). Movie messages on mass communication can take any form depending on the film's mission. However, generally, a film can include a variety of messages, be it educational, entertainment, or information messages. The message in the film is to use the symbolic mechanism that exists in the human mind in the form of message content, sound, speech, conversation, and so on. 
Films are also considered as a powerful communication medium for the masses they target, because of their audio-visual nature, namely living images and sounds. With pictures and sound, films can tell a lot in a short time(Ainslie et al., 2005; Angarita, 2007; Mateer \& Li, 2008; Reinstein \& Snyder, 2005; Sang \& Xu, 2010). When watching a film, the audience seems to be able to penetrate space and time that can tell the life and can even influence the audience.

Films can be grouped into two basic divisions, namely the category of story films and non-story films(Sklar, 2012). Other opinions classify it into fiction and non-fiction films. Feature films are films that are produced based on stories composed and played by actors and actresses. In general, feature films are commercial in nature, meaning they are shown in theaters with a certain ticket price or shown on television with the support of certain advertising sponsors. Non-story films are films that take reality as the subject, namely recording reality rather than fiction about reality.

In its development, story films and non-story films influence each other and give birth to various types of films that have their characteristics, styles, and patterns. Story films to keep the audience's interest must be responsive to the times, meaning that the story must be better, professional processing with increasingly sophisticated editing techniques so that the audience does not feel cheated by certain tricks even as if the audience is an actor/actress in the film the. In making story films, a thought process and technical process are needed, namely in the form of searching for ideas, ideas, or stories that are worked on, while the technical process is in the form of artistic skills to turn any idea, idea, or story into a film that is ready to watch

\section{RESEARCH METHODOLOGY}

The research method used in this research is the descriptive qualitative research method. Descriptive research is meant to identify, analyze, and describe data. The descriptive research method is research that is solely based on existing facts or phenomena that are empirically alive in the speakers so that the data produced or recorded is in the form of exposure. Furthermore, descriptive research does not consider whether or not the use of language by its speakers is true, because this is its first and foremost characteristic (Creswell, 2013).

\section{Instruments}

The basic technique used is listening to the use of the language spoken by the characters. While the advanced technology used is the listening technique, listen and watching the movie, again and again, the listening method is the provision of data by listening to the use of the language used by the characters. Then, data collection techniques were also carried out by recording techniques, recording words in speech sentences classified as mixed codes, and then analyzed. The recording was only done on data that would support this research 


\section{Data Analysis Procedures}

Data analysis was carried out while data collection was in progress. This means that the data that has been obtained is directly analyzed. Cresswell in qualitative research said that researchers should not wait and let the data accumulate to then analyze it. This method is taken to avoid data accumulation.

\section{RESULTSS AND DISCUSSION}

\section{Results}

The data is classified in this section based on the type and level of code-mixing. The data obtained from the London to Bali film is the subject of the study. Researchers discovered different types of code-mixing as well as different levels of code-mixing. The researcher analyzes the types of code-mixing and the level of code-mixing found in the movie using theory. According to suwito theory, there are two types of code-mixing, namely inner code-mixing, and outer code-mixing. Meanwhile, Suwito's level of codemixing includes word-level code-mixing, phrase-level code-mixing, clause-level codemixing, baster-level code-mixing, repetition of word-level code-mixing, and idiom-level code-mixing.

Table 1. The Findings Example Inner Code-Mixing

\begin{tabular}{|r|l|l|}
\hline No & \multicolumn{1}{|c|}{ Inner code-mixing } & \multicolumn{1}{c|}{ Analysis } \\
\hline 1. & Ini teh maksudnya apa yah & $\begin{array}{l}\text { the function of word teh is an affirmation } \\
\text { on the sentence }\end{array}$ \\
\hline 2. & $\begin{array}{l}\text { Mungkin sekitar 4 tahun, tenang aja } \\
\text { kita masih bisa kontek-kontekan }\end{array}$ & $\begin{array}{l}\text { The word "aja" is a Betawi dialect } \\
\text { commensurate with the word "saja" in } \\
\text { the Indonesian }\end{array}$ \\
\hline 3. & $\begin{array}{l}\text { Aku masih ngak nyangka deh kayak } \\
\text { mimpi rasanya }\end{array}$ & $\begin{array}{l}\text { The word "ngak" is equivalent to the } \\
\text { word "tidak", the word "no" is a language } \\
\text { that creates relaxation to friendship }\end{array}$ \\
\hline 4. & $\begin{array}{l}\text { Kebetulan kalau begitu rumah kita } \\
\text { kan kosong Cuma ada pembantu nah } \\
\text { kamu jagain aja sampai kita pulang } \\
\text { nanti yah }\end{array}$ & $\begin{array}{l}\text { "Jagain" is equivalent to the word "Jaga" } \\
\text { in Indonesian, the use of language is } \\
\text { influenced by the Balinese dialect which } \\
\text { is added by the suffix -in in the narrative }\end{array}$ \\
\hline 5. & $\begin{array}{l}\text { Mamang loe kepeleset di tangga } \\
\text { bambu. Bambunya licin terus } \\
\text { nafasnya sesak kambu? }\end{array}$ & $\begin{array}{l}\text { The word "loe" is equivalent to "kamu" } \\
\text { word in Indonesian }\end{array}$ \\
\hline 6. & $\begin{array}{l}\text { Gue mau bawa dia ke rumah sakit } \\
\text { dia ngak mau mesti nunggu elu }\end{array}$ & $\begin{array}{l}\text { The word "gue" is commensurate with } \\
\text { "saya" words in Indonesian, this is to } \\
\text { create relaxation or closeness }\end{array}$ \\
\hline
\end{tabular}




\begin{tabular}{|c|c|c|}
\hline No & Inner code-mixing & Analysis \\
\hline 7. & $\begin{array}{l}\text { Ngak papa bokap kerja di prancis } \\
\text { nyokap tinggal jadinya ikutan lah } \\
\text { aku tinggal sendirian, lagian aku } \\
\text { lebih nyaman ngobrol dengan orang } \\
\text { Indonesia }\end{array}$ & $\begin{array}{l}\text { The word "bokap" is a slang meaning } \\
\text { "bapak" in Indonesian, this describes the } \\
\text { relaxed conditions }\end{array}$ \\
\hline 8. & $\begin{array}{l}\text { Masa mobilnya bagus kayak gini } \\
\text { bensinnya abis }\end{array}$ & $\begin{array}{l}\text { The word "abis" from the Betawi dialect } \\
\text { is equivalent to the word "habis" in } \\
\text { Indonesian }\end{array}$ \\
\hline 9. & $\begin{array}{l}\text { Hei kok di konci, loe bohongin gue } \\
\text { hah }\end{array}$ & $\begin{array}{l}\text { The word konci is a dialect Betawi } \\
\text { equivalent to the word " kunci" in } \\
\text { Indonesian }\end{array}$ \\
\hline 10 & $\begin{array}{l}\text { Nih kalau di benarin bisa abis } 3 \text { juta } \\
702 \text { rebu lah }\end{array}$ & $\begin{array}{l}\text { The word rebu comes from the } \\
\text { Sundanese dialect which means ribu in } \\
\text { Indonesian }\end{array}$ \\
\hline 11 & $\begin{array}{l}\text { Buat die nih nih ngopi, emang ngak } \\
\text { ngopi orang gimana sih loe }\end{array}$ & $\begin{array}{l}\text { The word die is a Betawi dialect which is } \\
\text { commensurate with "die" word in } \\
\text { Indonesian }\end{array}$ \\
\hline 12 & $\begin{array}{l}\text { Kang atuh di bantulah kang, } \\
\text { tolongin lah kang di apain gitu? }\end{array}$ & $\begin{array}{l}\text { The word "tolongin" is commensurate } \\
\text { with the word tolong in Indonesian, in } \\
\text { speech add the suffix - in which is } \\
\text { influenced by the Balinese dialect }\end{array}$ \\
\hline 13 & $\begin{array}{l}\text { Gue mau ceritain sedikit tentang bali } \\
\text { yah jadi turis-turis di sini ngabisin } \\
\text { uangnya itu untuk kesenangan dan } \\
\text { kepuasannya mereka, anak-anak } \\
\text { pantai di sini meraup uang dari turis } \\
\text { itu. contohnya itu di sana awalnya } \\
\text { sih mijit malemnya langsung di lilit } \\
\text { dapet duit tuh bocah jelek. Terus } \\
\text { yang di sana modusnya suh ngajarin } \\
\text { selancar abis itu selancar di kamar } \\
\text { dapet dollar dan satu lagi tuh di } \\
\text { sebelah sana tuh bule udah ke patil } \\
\text { ama si kurus duit ngalir terus }\end{array}$ & $\begin{array}{l}\text { The word "bocah" is Betawi dialect which } \\
\text { means "little child" in Indonesian }\end{array}$ \\
\hline 14 & $\begin{array}{l}\text { Loe tuh bego atau gimana sih } \\
\text { katanya loe mau ngikutin cara kerja } \\
\text { gue, sekarang terserah loe deh, loe } \\
\text { mau jadi gembel juga boleh }\end{array}$ & $\begin{array}{l}\text { The word "bego" comes from the Betawi } \\
\text { dialect which is commensurate with the } \\
\text { "Sangat bodoh" in the Indonesian } \\
\text { language which causes ICM }\end{array}$ \\
\hline
\end{tabular}


Andi Asrifan, et. al: An Analysis of Code-Mixing In The Movie "From London To Bali" - 325

\begin{tabular}{|r|l|l|}
\hline No & \multicolumn{1}{|c|}{ Inner code-mixing } & \multicolumn{1}{c|}{ Analysis } \\
\hline 15 & $\begin{array}{l}\text { Cakep tuh hehehe, satu lagi mulai } \\
\text { sekarang loe harus panggil gue bos? } \\
\text { Ok }\end{array}$ & $\begin{array}{l}\text { The word "cakep" is a Betawi dialect } \\
\text { which means "bagus" in Indonesian }\end{array}$ \\
\hline 16 & $\begin{array}{l}\text { Pekerjaan ini sangat menyenangkan } \\
\text { dan menguntungkan ya udah bawel }\end{array}$ & $\begin{array}{l}\text { The word "bawel" is a Betawi dialect } \\
\text { which if interpreted in Indonesian means } \\
\text { "banyak bicara" }\end{array}$ \\
\hline 17 & $\begin{array}{l}\text { Udah loe ngak usah mikirin isi } \\
\text { kontraknya udah tanda tangan aja }\end{array}$ & $\begin{array}{l}\text { The word "mikirin" is commensurate } \\
\text { with the word "memikirkan" in } \\
\text { Indonesian, in the speech plus the suffix - } \\
\text { in which is influenced by the Balinese } \\
\text { language }\end{array}$ \\
\hline 18 & $\begin{array}{l}\text { Kenalin ini sodikin dan ini bambang } \\
\text { nih satu angkatan sama loe }\end{array}$ & $\begin{array}{l}\text { The word "kenalin" is commensurate } \\
\text { with the word "perkenalkan" in } \\
\text { Indonesian, in the speech plus the suffix - } \\
\text { in which is influenced by the Balinese } \\
\text { dialect }\end{array}$ \\
\hline 19 & $\begin{array}{l}\text { Kalian perhatiin gue yah ! } \\
\text { Nah sekarang kalian harus banyak } \\
\text { olahraga supaya badan jadi kekar } \\
\text { dan seksi, dan sekarang juga harus } \\
\text { bisa kenalan dan ajak cewek bule } \\
\text { ngerti kalian }\end{array}$ & $\begin{array}{l}\text { "Ajak" comes from the Betawi dialect } \\
\text { which is equivalent to the word } \\
\text { "meminta" in Indonesian }\end{array}$ \\
\hline
\end{tabular}

Table 2. The Findings Outer Code-Mixing

\begin{tabular}{|l|l|l|}
\hline NO & \multicolumn{1}{|c|}{ Outer code-mixing } & \multicolumn{1}{c|}{ Analysis } \\
\hline 1. & $\begin{array}{l}\text { aku tau kamu masih ngak rela aku } \\
\text { pergi tapi kalau kamu emang } \\
\text { sayang sama aku harusnya kamu } \\
\text { support aku }\end{array}$ & $\begin{array}{l}\text { In addition to being categorized in the } \\
\text { OCM because there is a word of support } \\
\text { in the speech that is inserted between } \\
\text { Indonesian languages, this shows that the } \\
\text { speaker is an educated person }\end{array}$ \\
\hline 2. & $\begin{array}{l}\text { Keep in touch Keep smile and keep } \\
\text { talking sama pembantu } \\
\text { OCM because the speaker uses English as } \\
\text { the main code then uses Indonesian as a } \\
\text { second language which is only fragments } \\
\text { in the use of the language }\end{array}$ \\
\hline 3. & $\begin{array}{l}\text { Ya udah di gadai 500 yah tapi 2 } \\
\text { dua ) bulan kalau ngak di tebus } \\
\text { nih motor milik gua, deal? }\end{array}$ & $\begin{array}{l}\text { The word "deal" is an English word that } \\
\text { means to "sepakat" in Indonesian, the } \\
\text { word deal has been used in the } \\
\text { Indonesian language }\end{array}$ \\
\hline
\end{tabular}




\begin{tabular}{|c|c|c|}
\hline NO & Outer code-mixing & Analysis \\
\hline 4. & $\begin{array}{l}\text { No, just boyfriend, hey this is } \\
\text { London bukan Indonesia }\end{array}$ & $\begin{array}{l}\text { In addition to being categorized in OCM } \\
\text { because speakers use English as the main } \\
\text { code and then insert the word "bukan" } \\
\text { which is Indonesian }\end{array}$ \\
\hline 5. & $\begin{array}{l}\text { We haha welcome to Bali surga } \\
\text { dunia.Sini minum dulu loe kan } \\
\text { capek }\end{array}$ & $\begin{array}{l}\text { In addition to being categorized in OCM } \\
\text { because there is the word welcome to in } \\
\text { a speech that is inserted between } \\
\text { Indonesian languages. This is used by } \\
\text { speakers to make it easier for opponents } \\
\text { to understand }\end{array}$ \\
\hline 6. & $\begin{array}{l}\text { Maaf aku baru sempat balas, } \\
\text { kemarin aku dapat surprise party }\end{array}$ & $\begin{array}{l}\text { In addition to being categorized in the } \\
\text { OCM because there is the word "surprise } \\
\text { party" in the narrative that is inserted } \\
\text { between Indonesian languages, this } \\
\text { shows that the speaker is an educated } \\
\text { person }\end{array}$ \\
\hline 7. & $\begin{array}{l}\text { Selamat datang di basecamp kuta } \\
\text { koboi, mulai hari ini lu akan } \\
\text { menjalankan hidup loe yang } \\
\text { menyenangkan dan banyak funnya } \\
\text { gi mana asik kan yuk } \\
\end{array}$ & $\begin{array}{l}\text { In addition to being categorized in the } \\
\text { OCM because there is a word" base camp" } \\
\text { in the narrative that is inserted between } \\
\text { Indonesian languages, aims to create a } \\
\text { friendly and relaxed atmosphere }\end{array}$ \\
\hline 8. & $\begin{array}{l}\text { Sekarang peraturan nomor } 2 \text { harus } \\
\text { nurut jadi tamu minta apa aja lo } \\
\text { turutin kalau tamu complaint loh } \\
\text { ngak dapat dit sepeser pun. }\end{array}$ & $\begin{array}{l}\text { In addition to being categorized in the } \\
\text { OCM, there is the word complaint in the } \\
\text { word which means complaining but this } \\
\text { is done because there is no right word to } \\
\text { use in the word }\end{array}$ \\
\hline 9. & $\begin{array}{l}\text { We haha welcome to Bali surga } \\
\text { dunia.Sini minum dulu loe kan } \\
\text { capek }\end{array}$ & $\begin{array}{l}\text { categorized in OCM because two } \\
\text { languages are used in each other in } \\
\text { which Indonesian is the main code than } \\
\text { English }\end{array}$ \\
\hline 10. & $\begin{array}{l}\text { Harus pake HP ini karena HP ini } \\
\text { sudah di install buat kerjaan loe } \\
\text { nanti }\end{array}$ & $\begin{array}{l}\text { The word install is used because there is } \\
\text { no equivalent word that can be used in } \\
\text { Indonesian }\end{array}$ \\
\hline 11. & $\begin{array}{l}\text { Halo sodikin nama ku tapi you can } \\
\text { call me dik saja }\end{array}$ & $\begin{array}{l}\text { The speaker said "you can call me" to } \\
\text { make a look familiar and friendly }\end{array}$ \\
\hline 12. & $\begin{array}{l}\text { Pekerjaan escort itu pekerjaan } \\
\text { yang sangat mulia kita berada di } \\
\text { garda terdepan untuk memberikan } \\
\text { impresi yang baik buat para turis } \\
\text { di Bali }\end{array}$ & $\begin{array}{l}\text { The word escort is an English word } \\
\text { meaning escort in Indonesian, the word } \\
\text { escort is used because of the name of a } \\
\text { job }\end{array}$ \\
\hline
\end{tabular}


Andi Asrifan, et. al: An Analysis of Code-Mixing In The Movie "From London To Bali" - 327

\begin{tabular}{|c|c|c|}
\hline NO & Outer code-mixing & Analysis \\
\hline 13. & $\begin{array}{l}\text { Ini role model kalian, kalian mesti } \\
\text { belajar sama dia. }\end{array}$ & $\begin{array}{l}\text { categorized in OCM because there are } \\
\text { foreign languages spoken in the language }\end{array}$ \\
\hline 14. & $\begin{array}{l}\text { Lihat elu kalau gue udah six pack } \\
\text { bapak elu datang mohon-mohon } \\
\text { gue tolak elu, sombong elu. }\end{array}$ & $\begin{array}{l}\text { The word "six-pack " categorize as OCM } \\
\text { because the word from English slipped } \\
\text { into Indonesian }\end{array}$ \\
\hline 15. & $\begin{array}{l}\text { Nah baru sejam foto loe gue } \\
\text { upload udah aja pelanggan loe, } \\
\text { emang kalau muka ganteng itu } \\
\text { ngak bisa boong hehehe, } \\
\text { bamabang sodikin tenang aja kalau } \\
\text { muka jelek ngak bisa boong }\end{array}$ & $\begin{array}{l}\text { the word "upload" comes from English } \\
\text { which is inserted between Indonesian } \\
\text { languages so that it is categorized in } \\
\text { OCM, the word upload is used because } \\
\text { there is no equivalent word }\end{array}$ \\
\hline 16. & Sorry for kentut & $\begin{array}{l}\text { The word "kentut" is Indonesian which is } \\
\text { slipped in between English, this shows } \\
\text { that the speaker can use Indonesian }\end{array}$ \\
\hline 17. & $\begin{array}{l}\text { Lukman selamat yah kemarin loe } \\
\text { itu } \text { CEO dari perusahaan } \\
\text { deodorant ternama di luar negeri } \\
\text { dan masih single hehehe nih, aits } \\
\text { ini langsung gue potong buat bayar } \\
\text { hutang, gue Cuma mau ngasih lihat } \\
\text { kalau loe dapat duit banyak }\end{array}$ & $\begin{array}{l}\text { The word CEO comes from English } \\
\text { namely Chief Executive Officer which } \\
\text { means " direktur utama" in Indonesian, } \\
\text { this word is used so that the interlocutor } \\
\text { understands more quickly what is meant. } \\
\text { then there is the word deodorant and } \\
\text { single on the speaker said because } \\
\text { nothing commensurate to that word. }\end{array}$ \\
\hline 18. & $\begin{array}{l}\text { Ini klien loe itu masuk penjara jadi } \\
\text { ngak dapat tip, tapi jangan sedih } \\
\text { memang kalau anggota baru itu } \\
\text { kebanyakan apes. Good berarti } \\
\text { sekarang gue mau pamit ke Jakarta } \\
\text { untuk urusan yang lain. Ok, take } \\
\text { care and have fun, ok guys }\end{array}$ & $\begin{array}{l}\text { categorized in OCM because speakers use } \\
\text { Indonesian and then mix with sentences } \\
\text { from English, this illustrates that } \\
\text { speakers of educated people }\end{array}$ \\
\hline 19. & Eh astagfirullah maaf-maaf. & $\begin{array}{l}\text { categorized in OCM because speakers } \\
\text { mix in Arabic, this is done because of } \\
\text { language requirements }\end{array}$ \\
\hline 20. & $\begin{array}{l}\text { Itung-itung aku fitnest biar perut } \\
\text { aku ini six pack }\end{array}$ & $\begin{array}{l}\text { the word fitness is used because there is } \\
\text { no equivalent word }\end{array}$ \\
\hline 21. & $\begin{array}{l}\text { Itung-itung aku fitnest biar perut } \\
\text { aku ini six pack }\end{array}$ & $\begin{array}{l}\text { the word fitnest is used because there is } \\
\text { no equivalent word }\end{array}$ \\
\hline
\end{tabular}


Table 3. Word Level Code-Mixing

\begin{tabular}{|c|c|c|c|}
\hline No & Context & $\begin{array}{l}\text { Level of } \\
\text { code- } \\
\text { mixing }\end{array}$ & Analysis \\
\hline 1. & $\begin{array}{l}\text { Loe tuh bego atau gimana sih } \\
\text { katanya loe mau ngikutin cara } \\
\text { kerja gue, sekarang terserah loe } \\
\text { deh loe mau jadi gembel juga boleh }\end{array}$ & WLCM & $\begin{array}{l}\text { there is the word "stupid" } \\
\text { which is categorized as } \\
\text { mixing basic word codes } \\
\text { because it has not } \\
\text { undergone any } \\
\text { morphological processes }\end{array}$ \\
\hline 2. & $\begin{array}{l}\text { Cakep tuh hehehe, satu lagi mulai } \\
\text { sekarang loe harus panggil gue } \\
\text { bos? Ok }\end{array}$ & WLCM & $\begin{array}{l}\text { the word "cakep " is } \\
\text { classified in the basic } \\
\text { word because it can't be } \\
\text { broken into smaller }\end{array}$ \\
\hline 3. & $\begin{array}{l}\text { Pekerjaan ini sangat } \\
\text { menyenangkan dan } \\
\text { menguntungkan ya udah bawel }\end{array}$ & WLCM & $\begin{array}{l}\text { The word "bawel" is basic } \\
\text { because the word cannot } \\
\text { be broken down into } \\
\text { smaller / simpler } \\
\text { elements. }\end{array}$ \\
\hline 4. & $\begin{array}{l}\text { Pekerjaan escort itu pekerjaan } \\
\text { yang sangat mulia kita berada di } \\
\text { garda terdepan untuk memberikan } \\
\text { impresi yang baik buat para turis di } \\
\text { Bali }\end{array}$ & WLCM & $\begin{array}{l}\text { The word "Escort" can be } \\
\text { categorized as a basic } \\
\text { word because the word } \\
\text { cannot be broken down } \\
\text { into smaller / simpler } \\
\text { elements. }\end{array}$ \\
\hline 5. & $\begin{array}{l}\text { Nah sekarang kalian harus banyak } \\
\text { olahraga supaya badan jadi kekar } \\
\text { dan seksi, dan sekarang juga harus } \\
\text { bisa kenalan dan ajak cewek bule, } \\
\text { ngerti kalian }\end{array}$ & WLCM & $\begin{array}{l}\text { The word "ajak" can be } \\
\text { classified into basic words } \\
\text { because they are the basis } \\
\text { for the formation of more } \\
\text { complex words. In } \\
\text { addition, the word cannot } \\
\text { be broken down anymore. }\end{array}$ \\
\hline 6. & $\begin{array}{l}\text { Nah baru sejam foto loe gue upload } \\
\text { udah aja pelanggan loe, emang } \\
\text { kalau muka ganteng itu ngak bisa } \\
\text { boong hehehe, bambang sodikin } \\
\text { tenang aja kalau muka jelek ngak } \\
\text { bisa boong }\end{array}$ & WLCM & $\begin{array}{l}\text { The word upload can be } \\
\text { classified as compound } \\
\text { words because the word } \\
\text { comes from the word up + } \\
\text { load. }\end{array}$ \\
\hline 7. & Sorry for kentut & WLCM & $\begin{array}{l}\text { The word" kentut" is } \\
\text { basic because the word } \\
\text { cannot be broken down }\end{array}$ \\
\hline
\end{tabular}


Andi Asrifan, et. al: An Analysis of Code-Mixing In The Movie "From London To Bali" - 329

\begin{tabular}{|c|c|c|c|}
\hline No & Context & $\begin{array}{c}\text { Level of } \\
\text { code- } \\
\text { mixing }\end{array}$ & Analysis \\
\hline & & & $\begin{array}{l}\text { into smaller / simpler } \\
\text { elements. }\end{array}$ \\
\hline 8. & $\begin{array}{l}\text { Ini klien loe itu masuk penjara jadi } \\
\text { ngak dapat tip, tapi jangan sedih } \\
\text { memang kalau anggota baru itu } \\
\text { kebanyakan apes. Good berarti } \\
\text { sekarang gue mau pamit ke }\end{array}$ & WLCM & $\begin{array}{l}\text { The word "good" can be } \\
\text { categorized as a basic } \\
\text { word because the word } \\
\text { cannot be broken down } \\
\text { into smaller / simpler } \\
\text { elements. }\end{array}$ \\
\hline 9. & $\begin{array}{l}\text { Gue pengen banyak duit, gue } \\
\text { pengen jadi orang kaya, } \\
\text { berangkatin orang tua ke mekkah } \\
\text { yah pokonya supaya ngak di } \\
\text { remehin orang. }\end{array}$ & WLCM & $\begin{array}{l}\text { The word pengen is basic } \\
\text { because the word cannot } \\
\text { be broken down into } \\
\text { smaller / simpler } \\
\text { elements. }\end{array}$ \\
\hline 10. & Mane teh Ngotor-ngotorin Bali aja & WLCM & $\begin{array}{l}\text { The word "mane" is basic } \\
\text { because the word cannot } \\
\text { be broken down into } \\
\text { smaller / simpler } \\
\text { elements. }\end{array}$ \\
\hline 11. & $\begin{array}{l}\text { Udah loe ngak usah mikirin isi } \\
\text { kontraknya udah tanda tangan aja }\end{array}$ & WLCM & $\begin{array}{l}\text { "Mikirin" of WLCM is } \\
\text { categorized as having an } \\
\text { impact because the word } \\
\text { comes from the word base } \\
\text { mikir added the suffix-in }\end{array}$ \\
\hline 12. & $\begin{array}{l}\text { Ah bule gelo mane teh ngak bisa } \\
\text { naik motor }\end{array}$ & WLCM & $\begin{array}{l}\text { The word "gelo" is basic, } \\
\text { because the word cannot } \\
\text { be broken down into } \\
\text { smaller / simpler } \\
\text { elements. }\end{array}$ \\
\hline 13. & $\begin{array}{l}\text { Ngak, anter ke rumah paman ku } \\
\text { nah dia bisa ngurut }\end{array}$ & WLCM & $\begin{array}{l}\text { The word "anter" is basic } \\
\text { because the word cannot } \\
\text { be broken down into } \\
\text { smaller / simpler } \\
\text { elements. }\end{array}$ \\
\hline 14. & $\begin{array}{l}\text { Ya udah atuh kamu tunjukin } \\
\text { jalannya yah }\end{array}$ & WLCM & $\begin{array}{l}\text { The word "atuh" is basic } \\
\text { because the word cannot } \\
\text { be broken down into } \\
\text { smaller / simpler } \\
\text { elements. }\end{array}$ \\
\hline
\end{tabular}




\begin{tabular}{|c|c|c|c|}
\hline No & Context & $\begin{array}{l}\text { Level of } \\
\text { code- } \\
\text { mixing }\end{array}$ & Analysis \\
\hline 15. & $\begin{array}{l}\text { Sampun, untung lansung di bawa } \\
\text { ke sini }\end{array}$ & WLCM & $\begin{array}{l}\text { The word "sampun" is } \\
\text { basic because the word } \\
\text { cannot be broken down } \\
\text { into smaller / simpler } \\
\text { elements. }\end{array}$ \\
\hline 16. & Udah aku antarin lagi & WLCM & $\begin{array}{l}\text { categorized as a word with } \\
\text { an impact because the } \\
\text { word "Antarin" comes } \\
\text { from an "antar" base word } \\
\text { added the suffix -in }\end{array}$ \\
\hline 17. & $\begin{array}{l}\text { Ya udah entar kalau kamu mau } \\
\text { pake motor kamu telpon aku aja }\end{array}$ & WLCM & $\begin{array}{l}\text { the word "use" is classified } \\
\text { in the basic word because } \\
\text { it cannot be changed again } \\
\text { in a simple form }\end{array}$ \\
\hline 18. & $\begin{array}{l}\text { Mane teh cari mejanya di pojok aja, } \\
\text { kalau ada kipas angin pinjem beli } \\
\text { lakban yah }\end{array}$ & WLCM & $\begin{array}{l}\text { the pinjem "use" is } \\
\text { classified in the basic } \\
\text { word because it cannot be } \\
\text { changed again in a simple } \\
\text { form }\end{array}$ \\
\hline 19. & $\begin{array}{l}\text { Jadi kamu jauh-jauh ke sini Cuma } \\
\text { mau tanyain itu doang }\end{array}$ & WLCM & $\begin{array}{l}\text { the doang "use" is } \\
\text { classified in the basic } \\
\text { word because it cannot be } \\
\text { changed again in a simple } \\
\text { form }\end{array}$ \\
\hline 20. & Jangan-jangan bukan $\boldsymbol{j i}$ itu klien mu & WLCM & $\begin{array}{l}\text { the word "ji" is classified } \\
\text { in the basic word because } \\
\text { it cannot be changed again } \\
\text { in a simple form }\end{array}$ \\
\hline 21. & Ngak papa, jatoh dari tempat tidur & WLCM & $\begin{array}{l}\text { the word "jatoh" is } \\
\text { classified in the basic } \\
\text { word because it cannot be } \\
\text { changed again in a simple } \\
\text { form }\end{array}$ \\
\hline 22. & $\begin{array}{l}\text { Lukman please, biarin aku jalanin } \\
\text { hidup aku yang baru }\end{array}$ & WLCM & $\begin{array}{l}\text { the word "please" is } \\
\text { grouped in the basic word } \\
\text { because it cannot be } \\
\text { broken. it becomes } \\
\text { simpler }\end{array}$ \\
\hline
\end{tabular}


Andi Asrifan, et. al: An Analysis of Code-Mixing In The Movie "From London To Bali" - 331

\begin{tabular}{|c|l|c|l|}
\hline No & \multicolumn{1}{|c|}{ Context } & $\begin{array}{c}\text { Level of } \\
\text { code- } \\
\text { mixing }\end{array}$ & \multicolumn{1}{|c|}{ Analysis } \\
\hline 23. & $\begin{array}{l}\text { Kalian tuh harus makan banyak } \\
\text { biar gede badannya! }\end{array}$ & WLCM & $\begin{array}{l}\text { the word "please" is } \\
\text { grouped in the basic word } \\
\text { because it cannot be } \\
\text { broken. it becomes } \\
\text { simpler }\end{array}$ \\
\hline 24. & $\begin{array}{l}\text { Putu, kebetulan nih makan bareng } \\
\text { sini sini. Putu kenalin ini lukman } \\
\text { anggota baru gue }\end{array}$ & WLCM & $\begin{array}{l}\text { the word "please" is } \\
\text { grouped in the basic word } \\
\text { because it cannot be } \\
\text { broken. it becomes } \\
\text { simpler }\end{array}$ \\
\hline 25. & $\begin{array}{l}\text { Aduh seruisan ini atuh kalau ada } \\
\text { yang ngelangar gimana? }\end{array}$ & WLCM & $\begin{array}{l}\text { categorized as a word with } \\
\text { an impact because the } \\
\text { word "ngelanggar" comes } \\
\text { from a "langgar" base } \\
\text { word added the prefix - } \\
\text { nge }\end{array}$ \\
\hline
\end{tabular}

Table 4. Phrase-Level Code-Mixing in the Movie "From London to Bali

\begin{tabular}{|l|l|c|l|}
\hline No & \multicolumn{1}{|c|}{ Speech } & $\begin{array}{c}\text { Level of } \\
\text { code- } \\
\text { mixing }\end{array}$ & \multicolumn{1}{|c|}{ Analysis } \\
\hline 1. & $\begin{array}{l}\text { Innalillahi Wainnailaihi rajiun } \\
\text { mamang loe ude ngak ade }\end{array}$ & PLCM & $\begin{array}{l}\text { Innalillahi wainna ilaihi } \\
\text { rajiun is categorized in } \\
\text { phrases because it doesn't } \\
\text { have a combination of } \\
\text { subject and predicate but } \\
\text { already has meaning }\end{array}$ \\
\hline 2. & $\begin{array}{l}\text { Maaf aku baru sempat balas, } \\
\text { kemarin aku dapat surprise party }\end{array}$ & PLCM & $\begin{array}{l}\text { Surprise parties are } \\
\text { classified in phrases } \\
\text { because they have no } \\
\text { subject and predicate but } \\
\text { have meaning }\end{array}$ \\
\hline 3. & $\begin{array}{l}\text { Ini role model kalian, kalien mesti } \\
\text { belajar sama dia }\end{array}$ & PLCM & $\begin{array}{l}\text { Role models are classified } \\
\text { in phrases because they } \\
\text { have no subject and } \\
\text { predicate but have } \\
\text { meaning }\end{array}$ \\
\hline 4. & Keep contact yah & PLCM & $\begin{array}{l}\text { Keep contact are } \\
\text { classified in phrases }\end{array}$ \\
\hline
\end{tabular}




\begin{tabular}{|c|c|c|c|}
\hline No & Speech & $\begin{array}{l}\text { Level of } \\
\text { code- } \\
\text { mixing }\end{array}$ & Analysis \\
\hline & & & $\begin{array}{l}\text { because they have no } \\
\text { subject and predicate but } \\
\text { have meaning }\end{array}$ \\
\hline 5. & $\begin{array}{l}\text { Ini klien loe itu masuk penjara jadi } \\
\text { ngak dapat tip, tapi jangan sedih } \\
\text { memang kalau anggota baru itu } \\
\text { kebanyakan apes. Good berarti } \\
\text { sekarang gue mau pamit ke Jakarta } \\
\text { untuk urusan yang lain. Ok, take } \\
\text { care and have fun, ok guys }\end{array}$ & PLCM & $\begin{array}{l}\text { Take care and have fun } \\
\text { categorized in phrases } \\
\text { because it doesn't have a } \\
\text { combination of subject } \\
\text { and predicate but already } \\
\text { has meaning }\end{array}$ \\
\hline 6. & Eh astagfirullah maaf-maaf. & PLCM & $\begin{array}{l}\text { Astagfirullah is } \\
\text { categorized in the phrase } \\
\text { form description of the } \\
\text { entry of the Arabic } \\
\text { language of speech }\end{array}$ \\
\hline 7. & $\begin{array}{l}\text { Lukman i'm serious kaki kamu } \\
\text { kenapa kayak gini? }\end{array}$ & PLCM & $\begin{array}{l}\text { I'm seriously categorized } \\
\text { in phrases because it } \\
\text { doesn't have a } \\
\text { combination of subject } \\
\text { and predicate but already } \\
\text { has meaning }\end{array}$ \\
\hline 8. & $\begin{array}{l}\text { Welcome to Bali surga dunia.Sini } \\
\text { minum dulu loe kan capek }\end{array}$ & PLCM & $\begin{array}{l}\text { categorized in phrases } \\
\text { because it doesn't have a } \\
\text { combination of subject } \\
\text { and predicate but already } \\
\text { has meaning }\end{array}$ \\
\hline 9. & $\begin{array}{l}\text { From London to Bali tujuan kamu } \\
\text { tuh apa sih? }\end{array}$ & PLCM & $\begin{array}{l}\text { categorized in phrases } \\
\text { because it doesn't have a } \\
\text { combination of subject } \\
\text { and predicate but already } \\
\text { has meaning }\end{array}$ \\
\hline
\end{tabular}

Table 5. Clause Level Code-Mixing in the Movie "From London to Bali

\begin{tabular}{|l|l|c|l|}
\hline No & \multicolumn{1}{|c|}{ Speech } & $\begin{array}{c}\text { Level of } \\
\text { code- } \\
\text { mixing }\end{array}$ & \multicolumn{1}{|c|}{ Analysis } \\
\hline 1. & $\begin{array}{l}\text { Halo sodikin nama ku tapi you can } \\
\text { call } \text { me dik saja }\end{array}$ & CLCM & $\begin{array}{l}\text { You can call me } \\
\text { categorized in clause } \\
\text { because it consists of a }\end{array}$ \\
\hline
\end{tabular}


Andi Asrifan, et. al: An Analysis of Code-Mixing In The Movie "From London To Bali" - 333

\begin{tabular}{|l|l|c|l|}
\hline No & \multicolumn{1}{|c|}{ Speech } & $\begin{array}{c}\text { Level of } \\
\text { code- } \\
\text { mixing }\end{array}$ & \multicolumn{1}{|c|}{ Analysis } \\
\hline 2. & $\begin{array}{l}\text { Hai, I miss you so much akhhirnya } \\
\text { kita bisa ketemu lagi sama kamu. } \\
\text { Aku tuh nunggu udah lama banget } \\
\text { untuk ketemu sama kamu }\end{array}$ & CLCM & $\begin{array}{l}\text { combination of words that } \\
\text { have subject and predicate }\end{array}$ \\
\hline 3. & $\begin{array}{l}\text { I miss you so much } \\
\text { categorized in } \\
\text { independent clause } \\
\text { because the sentence can } \\
\text { stand alone and already } \\
\text { has a complete meaning }\end{array}$ \\
\hline $\begin{array}{l}\text { atuh berdiri } \text { mouth, emang teh } \\
\text { hamomg apaan, sini }\end{array}$ & CLCM & $\begin{array}{l}\text { What your mouth } \\
\text { categorized in } \\
\text { independent clause } \\
\text { because the sentence can } \\
\text { stand alone and already } \\
\text { has a complete meaning }\end{array}$ \\
\hline 4. & $\begin{array}{l}\text { I think it, ngak ada apa-apanya di } \\
\text { banding kecantikan kamu }\end{array}$ & CLCM & $\begin{array}{l}\text { think it } \text { categorized in } \\
\text { clause because it has } \\
\text { elements of subject and } \\
\text { predicate }\end{array}$ \\
\hline
\end{tabular}

Table 6. Baster Level Code-Mixing in the Movie "From London to Bali

\begin{tabular}{|l|l|c|l|}
\hline No & \multicolumn{1}{|c|}{ Speech } & $\begin{array}{c}\text { Level of } \\
\text { code- } \\
\text { mixing }\end{array}$ & \multicolumn{1}{|c|}{ Analysis } \\
\hline 1. & $\begin{array}{l}\text { Selamat datang di basecamp kuta } \\
\text { koboi, mulai hari ini lu akan } \\
\text { menjalankan hidup loe yangn } \\
\text { menyenangkan dan banyak funnya } \\
\text { gi mana asik kan yuk }\end{array}$ & BLCM & $\begin{array}{l}\text { there is the word "fun" in } \\
\text { the story which when } \\
\text { viewed the word fun } \\
\text { comes from English and } \\
\text { then -nya from Indonesian } \\
\text { this is what causes BLCM }\end{array}$ \\
\hline
\end{tabular}

Table 7. Repetition Word-Level Code-Mixing in the Movie "From London to Bali

\begin{tabular}{|l|l|c|l|}
\hline No & \multicolumn{1}{|c|}{ Speech } & $\begin{array}{c}\text { Level of } \\
\text { code- } \\
\text { mixing }\end{array}$ & \multicolumn{1}{|c|}{ Analysis } \\
\hline 1. & $\begin{array}{l}\text { Itung-itung aku fitnest biar perut } \\
\text { aku ini sixpack }\end{array}$ & RWCM & $\begin{array}{l}\text { from the side is a repeated } \\
\text { word repeating all the } \\
\text { basic forms }\end{array}$ \\
\hline
\end{tabular}




\begin{tabular}{|l|l|c|l|}
\hline 2. & $\begin{array}{l}\text { Saya teh nyesal saya udah } \text { nyia- } \\
\text { nyiain hidup saya untuk pekerjaan } \\
\text { yang ngak benar }\end{array}$ & RWCM & $\begin{array}{l}\text { from the side is a repeat } \\
\text { word that gets an affix }\end{array}$ \\
\hline 3. & $\begin{array}{l}\text { Kita kan masih bisa } \text { kontek- } \\
\text { kontekan }\end{array}$ & RWCM & $\begin{array}{l}\text { from the side is a repeat } \\
\text { word that gets an affix }\end{array}$ \\
\hline
\end{tabular}

\section{Discussion}

Finally, the researchers discussed the findings from London to Bali movie through a long process. For types of code-mixing that are often used are inner codemixing (ICM) then Outer code-mixing (OCM). In from London to Bali movie uses language that is more relaxed and more intimate, this is done to attract the interest of the audience, both adults and adolescents watching from London to Bali movie, because it uses language that tends to be relaxed in its narrative. Then the level of code-mixing from London to Bali is not all code-mixing is used, of the six code-mixing levels examined only idioms of the level of code-mixing are not used in the form London to Bali movie. The most widely used level of code-mixing is the word level of code-mixing. It is obtained from the insertion of words in a sentence spoken from London to Bali this movie can be seen from the conditions, culture, and location of the shoot or the situation at the time of filming.

The second level is the phrase code level mixing (PLCM) obtained in from London to Bali movie, then the third is a clause then followed by a repetition of the word level code-mixing after that baster code-mixing. In Leech's opinion, politeness refers to forms of action that people follow to preserve their committees or create an environment of general harmony. According to the Leech theory, the use of euphemism is thus a maxim of negative politeness, aimed at preventing conflict rather than finding consensus. Euphemism helps prevent concepts that may trigger conflict in language which are threatening to face. The code change is often used to establish comedy from formal to slang, or urban. Humor is intended to minimize the severity of the HIV and AIDS topic that deals with serious issues such as disease and death by laughing. In Mashiri and As Lederer (1997: 4) cited. Al. (2002: 231) quite rightly argued that 'slang helps us to crack the ice through cheaper and friendlier equipment' In Skido for example, it produces a humorous effect, saying "I like this one with a large backbone." The bits of slang used in a formal language is intended to draw the audience's attention with hilariousness since the intention is to laugh and learn. This approach takes the form of edutaining contact in the sense of the film, which 
simultaneously provides for and educates. It is a compelling tactic to encourage people to listen, understand and potentially change their risky sexual behavior.

The switch of code between languages serves various purposes of communication. It can be a way of claiming a common identity and a method used by two people to create relationships among the interlocutors. In the above example, when the gardener becomes Black, Tiyane switches to Shona. Shona is used in this scenario to assert the same ethnic identity with the gardens, thus eliminating barriers to contact between the two. There is friction initially between the two aliens, but when they turn to Shona this is minimized. Similarly, Adriane-Los (1997) of Asian Americans researched code-switching to classify ethnic groups. Code shift was made. These occurrences are much closer to the truth of the cinema's vocabulary as they reflect the same condition as in society. Tisane speaks in English to Juliet and her mother, but when he talks with the gardener, she returns to Shona. In this regard, the change of code is intended to accommodate a person not competent in a certain language, as with the gardener who is not competent in the English language. Concerning Indonesia's socio-cultural today, Socio-cultural value is a foundation of every person's life because it is associated with fundamental values such as good or bad, right or wrong, usual or unusual, and is thought to be important in ensuring a society's longterm development (Koentjaraningrat, 1974). It has a significant impact on and determines the knowledge system (way of thinking) and how individuals and groups act and behave. The socio-cultural values that will be explored in this paper will primarily be in education, which is a deliberate effort and is intended to develop the individual potential to develop community, nation, and even the state.

\section{CONCLUSION}

Finally, the researchers discussed the findings from London to Bali movie through a long process. For types of code-mixing that are often used are inner codemixing (ICM) then Outer code-mixing (OCM). In from London to Bali movie uses language that is more relaxed and more intimate, this is done to attract the interest of the audience, both adults and adolescents watching from London to Bali movie, because it uses language that tends to be relaxed in its narrative.

\section{REFERENCES}

Adrean, M. R., Daud, B., \& Kismullah, K. (2019). An Analysis of Code-mixing in 
Indonesian Movie Cek Toko Sebelah. Research in English and .... Retrieved from http://www.jim.unsyiah.ac.id/READ/article/view/14122/0.

Ainslie, A., Drèze, X., \& Zufryden, F. (2005). Modeling movie life cycles and market share. Marketing Science. Retrieved from https://pubsonline.informs.org/doi/abs/10.1287/mksc.1040.0106.

Angarita, O. E. P. (2007). Movie player. US Patent App. 29/255,450. Retrieved from https://patents.google.com/patent/USD552054S1/en.

Apriani, E., Supardan, D., Sartika, E., Suparjo, S., \& Hakim, I. N. (2019). Utilizing ICT to develop student's language ethic at Islamic university. POTENSIA: Jurnal Kependidikan Islam, 5(1), 1-14.

Bhatia, T. K., \& Ritchie, W. C. (2014). The handbook of bilingualism and multilingualism. Retrieved from https://books.google.com/books?hl=en\&lr=\&id=b3PYAwAAQBAJ\&oi=fnd\&pg=P $\mathrm{R} 11 \& \mathrm{dq}=$ the + handbook+of+bilingualism+and+multilingualism\&ots=GUlzJjVG61 \&sig=xcj5MBDMu9p4Be7UXaGR3dfFyww.

Blommaert, J. (2010). The sociolinguistics of globalization. Retrieved from https://books.google.com/books?hl=en\&lr=\&id=YQwyVlYWa8MC\&oi=fnd\&pg=P R7\&dq=introducing+sociolinguistic\&ots=xAgqvTIh3v\&sig=5EcBiLsZtYdAtAYHxltga6Lu54.

Busby, G., \& Klug, J. (2001). Movie-induced tourism: The challenge of measurement and other issues. Journal of Vacation Marketing. Retrieved from https://journals.sagepub.com/doi/abs/10.1177/135676670100700403.

Butler, D. J., Wulff, J., Stanley, G. B., \& Black, M. J. (2012). A naturalistic open source movie for optical flow evaluation. European Conference on .... Retrieved from https://link.springer.com/chapter/10.1007/978-3-642-33783-3_44.

Creswell, J. W. (2013). Research Design: Qualitative, Quantitative, and Mixed Methods Approaches, 4th Edition (4th edition). Thousand Oaks: SAGE Publications, Inc.

Gabler, N. (2000). Life the movie: How entertainment conquered reality. Vintage.

Hamsia, W. (2015). Code-mixing And Code Switching in Umar Kayam's Novel Para Priyayi. Didaktis: Jurnal Pendidikan Dan Ilmu Pengetahuan. Retrieved from http://103.114.35.30/index.php/didaktis/article/view/42.

Harya, T. D. (2018). SOCIOLINGUISTICS (CODE: CODE-SWITCHING AND CODEMIXING). Lentera: Jurnal Ilmiah Kependidikan. Retrieved from http://jurnal.stkippgribl.ac.id/index.php/lentera/article/view/74.

Holmes, J. (2013). An introduction to sociolinguistics. Retrieved from https://books.google.com/books?hl=en\&lr=\&id=iV_fAQAAQBAJ\&oi=fnd\&pg=PP1 $\& d q=$ introducing+sociolinguistic\&ots=nNBecOzXyq\&sig=RmZ3ek_F8ZfdjI4AjVjjK SR9Mkk.

Hymes, D. (1971). Sociolinguistics and the ethnography of speaking. Social Anthropology and Language. Retrieved from https://books.google.com/books?hl=en\&lr=\&id=M0EEbntsmoC\&oi=fnd\&pg=PA47\&dq=introducing +sociolinguistic\&ots=vBgbnGoA_Y \&sig=7RI5WQe2ROSbFNgMOvC_oh0Yy1k. 
Koentjaraningrat. 1974. Manusia dan Kebudayaan di Indonesia. Djakarta: Djambatan. Leech, G. N. (1983). Principles of Pragmatics. London: Longman.

Mashiri, P., Mawomo, K., \& Iom, P. (2002) Naming the Pandemic: Semantic and Ethical Foundations of HIV/AIDS Shona Vocabulary. (University of Zimbabwe Zambezia Journal 2002, XX1X, ii)

Mateer, G. D., \& Li, H. (2008). Movie scenes for economics. The Journal of Economic Education. Retrieved

from https://www.tandfonline.com/doi/pdf/10.3200/JECE.39.3.303

Mendiburu, B. (2012). 3D movie making: stereoscopic digital cinema from script to screen.

Retrieved from https://books.google.com/books?hl=en\&lr=\&id=36B5AgAAQBAJ\&oi=fnd\&pg=PP $1 \& \mathrm{dq}=$ movie \&ots=r1802hmNHK\&sig=wxTj1_zf_zqcjOLgw8V6ZI7g2lk

Mesthrie, R. (2009). Introducing sociolinguistics. Retrieved from https://books.google.com/books?hl=en\&lr=\&id=sjIkDQAAQBAJ\&oi=fnd\&pg=PP1 $\& d q=$ introducing+sociolinguistic\&ots=qJOIpwj16A\&sig=XKDOdjLXyK8t_KgFG5h ORIdMyso

Meyerhoff, M. (n.d.). Introducing Sociolinguistics.

Moretti, E. (2011). Social learning and peer effects in consumption: Evidence from movie sales. The Review of Economic Studies. Retrieved from https://academic.oup.com/restud/article-abstract/78/1/356/1536231.

Nair, A., Auerbach, G., \& Skerlos, S. J. (2019). Environmental Impacts of Shifting from Movie Disc Media to Movie Streaming: Case Study and Sensitivity Analysis. Procedia CIRP, 80, 393-398. https://doi.org/https://doi.org/10.1016/j.procir.2019.01.102.

Pitaloka, A. (n.d.). AN ANALYSIS OF CODE-MIXING USED IN INSTAGRAM BY THE STUDENTS OF ENGLISH LANGUAGE EDUCATION. CONTENT OF TABLE. Retrieved from https://www.academia.edu/download/61695212/Proceedings_Paper_PBI4_Semester_720200106-65319-91jue0.pdf\#page=5.

Poudel, S. (2019). Code-Mixing and literal translation in Nepal's English newspapers. Journal of NELTA. Retrieved https://www.nepjol.info/index.php/NELTA/article/view/27692.

Rasul, S. (2013). Borrowing and code-mixing in Pakistani children's magazines: practices and functions. Pakistaniaat: A Journal of Pakistan Studies. Retrieved from http://www.academia.edu/download/57044741/228-Article_Text-419-2-1020131006.pdf.

Reinstein, D. A., \& Snyder, C. M. (2005). THE INFLUENCE OF EXPERT REVIEWS ON CONSUMER DEMAND FOR EXPERIENCE GOODS: A CASE STUDY OF MOVIE CRITICS*. The Journal of Industrial Economics. Retrieved from https://onlinelibrary.wiley.com/doi/abs/10.1111/j.0022-1821.2005.00244.x.

Rohrbach, A., Torabi, A., Rohrbach, M., Tandon, N., \& ... (2017). Movie description. International Journal of .... Retrieved from 
https://link.springer.com/content/pdf/10.1007/s11263-016-0987-1.pdf.

Sang, J., \& Xu, C. (2010). Character-based movie summarization. Proceedings of the 18th ACM International Conference .... Retrieved from https://dl.acm.org/doi/abs/10.1145/1873951.1874096?casa_token=jeDGTgvqn 3IAAAAA:8yZew9DnjC5UmCFXzljhUDM1r1xZSpYJMoy03pzTW74gPQr5USbwEbssyICoNs3v_ELJSp1zGgt.

Silviyani, E. (2018). AN ANALYSIS OF CODE-MIXING USED IN THE PROFESSIONAL MOVIE. Retrieved from http://eprints.uty.ac.id/918/.

Sklar, R. (2012). Movie-made America: A cultural history of American movies. Retrieved from

https://books.google.com/books?hl=en\&lr=\&id=IsyqGvM7nwQC\&oi=fnd\&pg=PA $1 \& d q=$ movie\&ots=f2xvMHrT7W\&sig=Xs4KADZklSFFVd043trLtB20QDw.

Sotiloye, B. (1992). Sociolinguistic: Introduction to Linguistics. Yusuf. Ed. Ilorin: University Press.

Trudgill, P. (2000). Sociolinguistics: An introduction to language and society. Penguin UK. Wray, A. (1998). An introduction to sociolinguistic. New York: Blackwell.

Zhang, W., \& Skiena, S. (2009). Improving movie gross prediction through news analysis. 2009 IEEE/WIC/ACM International Joint .... Retrieved from https://ieeexplore.ieee.org/abstract/document/5286056/. 